\title{
The Effect of Profitability and Liquidity on Firm Value with Leverage as Moderating Variable in Companies That are Joined in LQ45 and Listed on the Indonesia Stock Exchange for the Period 2007-2019
}

\author{
Regina Clara Febrinta Br Bukit ${ }^{1}$, Iskandar Muda ${ }^{1}$, Erwin Abubakar ${ }^{1}$ \\ ${ }^{1}$ Department of Accounting, Faculty of Economics and Business at Universitas Sumatera Utara, Indonesia
}

Corresponding Author: Regina Clara Febrinta Br Bukit

\begin{abstract}
The research objective was to examine and analyze the effect of profitability and liquidity on firm value in companies corporated in LQ 45 and listed on the Indonesia Stock Exchange and test whether leverage can moderate the relationship between the independent and dependent variables. This research is causal research using secondary data. The population of this study is companies that are members of the LQ45 on the Indonesia Stock Exchange from 2007 to 2019. The method of determining the sample uses purposive sampling so that a sample of 10 companies is multiplied by 13 years of research to obtain 130 observations. The analysis technique used in this study uses multiple linear regression analysis and moderating tests with the $\mathrm{R}$ Studio tools. The results of this study simultaneously profitability and liquidity have a significant effect on firm value. The results partially profitability has a significant positive effect on firm value, liquidity has an insignificant negative effect on firm value. Meanwhile, for simultaneous moderating, the results show that leverage can moderate the relationship between profitability and liquidity simultaneously on firm value, and partially leverage cannot moderate the relationship between profitability and firm value. Leverage is not able to moderate the relationship between liquidity and firm value.
\end{abstract}

Keywords: profitability, liquidity, leverage, firm value

\section{INTRODUCTION}

Entering the era of industry 4.0, companies need investors to help support the company's development. Companies must develop strategies for transformation and innovation to compete with other companies. One of the company's strategies is to increase company value. Firm value is a condition that describes the achievement of a company (Othman \& Haron, 2021). Where the value of the company is good, the company will be viewed well by potential investors. Firm value is an indicator used by investors to be used as a benchmark for assessing a company before investing.

Firm value is defined as investors' perception of the company's level of success in managing resources as reflected in the company's stock price at the end of the current year (Machmuddah et al., 2020). The higher the stock price, the higher the company's value and vice versa. With the lower company's stock price, the company's value will also be lower so that the company's performance will be considered less good (Husain et al., 2020). For companies that have not gone public, the company's value is some costs that prospective buyers are willing to pay if the company is sold. In contrast, for companies that have gone public, the company's value 
Regina Clara Febrinta Br Bukit et.al. The effect of profitability and liquidity on firm value with leverage as moderating variable in companies that are joined in LQ45 and listed on the Indonesia stock exchange for the period 2007-2019.

can be seen from the value of shares in the capital market (Mariana et al., 2020).

In this study, the indicator used for firm value is Price to Book Value (PBV). One of the advantages of PBV is that book value is a stable and simple measure that can be compared with market prices. PBV can also be compared between similar companies to show how expensive or cheap a stock is. This ratio can provide an overview of the potential price movements of a stock. PBV also shows the comparison between the stock price and the book value per share. When the PBV is high, it reflects that the stock market value is greater than the book value, so the company value is high. A high PBV reflects the level of prosperity of the shareholders, which is the company's main goal (Bukit \& Bakar, 2016).

The rise and fall of the average PBV ratio that reflects the value of companies that are members of LQ45 and listed on the Indonesia Stock Exchange (IDX) in 20072019 is an interesting phenomenon to talk about. The following is a phenomenon of fluctuations in company value which can be seen in Figure 1.1 below:

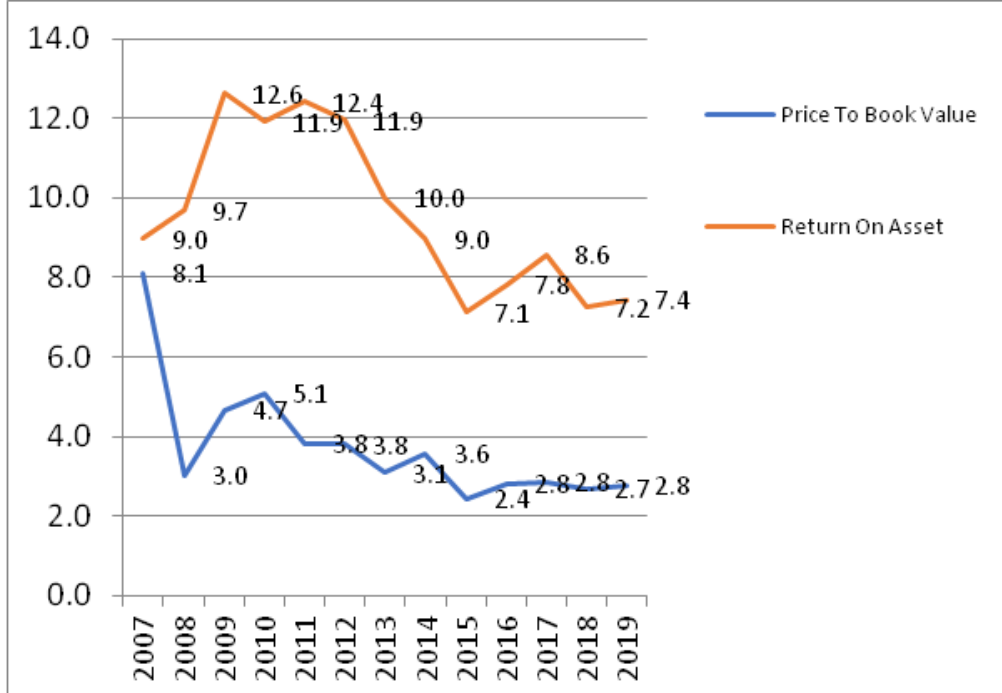

Figure 1.1. Average company value (PBV) and average profitability (ROA) in LQ45 companies 2007 - 2019

Figure 1.1 shows that in 2007-2008 the average PBV ratio decreased significantly from 8.1 to 3.0. Then there was a decline again in 2010-2011 from 5.1 to 3.83. The rise and fall of company value are caused by several factors: profitability, liquidity, leverage, size, activity, growth, audit quality, and so on (Dessyana, 2016). In this study, profitability and liquidity were taken as independent variables and leverage as a moderating variable.

The reason researchers take profitability because it can describe the ability of a company to generate profits at certain levels of sales, assets, and share capital (Pazos, Lopez, \& Arez, 2021). Profitability has an important meaning in the company because it affects the survival of the company in the long term, which shows whether the company has good prospects in the future. Profitability affects the policies of investors on the investments made. The company's ability to earn profits will attract investors to invest their funds to expand the business. Profitability for companies is used as an evaluation material for the effectiveness of company management, so profitability is a very important factor because it is directly related to the company's ability to carry out company operations (Rahayu \& Sari, 2018).

Profitability is a ratio to assess the company's ability to seek profit or profit, which measures the effectiveness of a company's management. Increased profitability will give investors confidence in the company and ultimately increase stock prices (Maani et al., 2021). The 
Regina Clara Febrinta Br Bukit et.al. The effect of profitability and liquidity on firm value with leverage as moderating variable in companies that are joined in LQ45 and listed on the Indonesia stock exchange for the period 2007-2019.

greater the profit obtained, the greater the company's ability to pay dividends. The bigger the dividend, the higher the value of the company. Besides that, high profits indicate good company prospects to trigger investors to increase demand for shares. In this study, profitability is measured using the Return On Asset (ROA) indicator. It describes the percentage value of profit (profit) obtained by the company related to resources or total assets. Therefore, a company's efficiency in managing its assets can be seen from this ratio (Puspitasari et al., 2021).

The results of Chumaidah and Priyadi's research (2018) show that profitability has a significant effect on firm value. These results are in line with research by Osazuwa \& Ahmad (2016), Sriwahyuni \& Wihandaru (2016), Hertina (2019), and Pratiwi et al. (2020). In contrast to the research of Kalbuana et al. (2021), which shows that profitability has no significant effect on firm value. However, Kodongo et al. (2021) say that profitability negatively affects firm value.

Profitability is closely related to liquidity because liquidity is related to its ability to fulfill its financial obligations that must be met. Liquidity is very important because it relates to the level of investor confidence in the company. After all, liquidity reflects the company's ability to pay its obligations according to the stipulated time. One of the considerations made by investors is by looking at how smoothly a company pays its debts (Janabi, 2021).

Liquidity is the company's ability to meet its financial obligations in the short term, using the company's current funds (Sukarya \& Baskara, 2019). A high level of liquidity reduces the company's failure to meet short-term obligations to creditors and vice versa. The high or low ratio will affect the interest of investors to invest their funds. If the company has a high liquidity value, its performance is good, increasing the stock price that reflects its value (Lalithchandra \& Rajendhiran, 2021). However, suppose the amount of working capital owned by the company is too high or excessive. It is not good because many sources of funds are idle or ineffective, which causes the company to lose the opportunity (opportunity lost) to obtain optimal profits. Therefore, it is necessary to determine the appropriate or efficient sources of funds to finance the company's working capital (Baz et al., 2021).

Through the liquidity ratio, company owners can assess management's ability to manage entrusted funds, including funds used to pay short-term obligations. Investors need liquidity ratios, especially in terms of cash dividend distribution, while creditors need it as a guideline for repayment of principal loans with interest. Creditors and suppliers will usually hand over loans/debts to companies with a high liquidity level (Czerwonka \& Jaworski, 2021).

One of the company's good conditions in managing internal and external resources is indicated by effective liquidity management. Companies must have a good level of availability of cash or other assets that can be converted into cash (Le \& Gregoriou, 2021). One of the company's representatives' abilities to pay the current debt is by using current assets. The liquidity factor has a crucial role in managing debt so that the profits obtained by the company can cover the debt (Setyawan et al., 2019). short it has. In this study, liquidity is measured using the Current Ratio (CR).

The research results conducted by Sari \& Suryantini (2019) showed that liquidity had a significant effect on firm value. This is reinforced by the research of Sukarya \& Baskara (2019), Putra and Lestari (2016), Du et al (2016), and Pratiwi (2020). It indicates that the higher the liquidity value, the higher the firm value.

The next variable that affects firm value is leverage. Leverage is an important factor because it affects its profitability, and shareholder wealth can be maximized when the company employs more debt. The use of corporate financing sources, both short-term financing sources and long-term financing 
Regina Clara Febrinta Br Bukit et.al. The effect of profitability and liquidity on firm value with leverage as moderating variable in companies that are joined in LQ45 and listed on the Indonesia stock exchange for the period 2007-2019.

sources, will cause an effect called leverage (Ganiyu et al., 2021). Leverage is caused by fixed-cost assets that increase the return of company owners. Increasing leverage causes an increase in risk and rate of return because leverage can affect the company's value. A financial manager must know how to measure and evaluate leverage (Chen et al., 2021).

Leverage is a ratio to measure the level of solvency of the company, where this ratio shows the company's ability to meet its financial obligations if the company goes into liquidation. So leverage can be understood as an interpreter of the risks inherent in the company, meaning that the greater the leverage indicates, the greater the investment risk and vice versa. When the leverage is low, the investment risk will be low (Astriani, 2014). When developing its potential, the company requires substantial capital, which can come from debt or equity. Debt has two important advantages. Firstly the interest paid can be a tax deduction. Secondly, creditors will get a fixed amount of return so that shareholders do not have to share the profits if the business goes very well (Rahayu \& Sari, 2018). In this study, leverage is measured using DER (Debt Equity Ratio).

Yang \& Suh's (2021) research shows that leverage has a significant effect on firm value. It is supported by the research of Ibrahim \& Isiaka (2021). It indicates that the higher the leverage, the higher the firm value in contrast to the results of Wabwile et al. (2014), which suggests that leverage does not affect firm value.

The researcher only takes the profitability and liquidity variables as independent variables because these two variables are vital variables for the company. Profitability is related to the company's ability to carry out activities. When profitability decreases, it will result in the cessation of the production process to experience listings. Liquidity and Profitability are two variables that are related to each other. In research (Guragai, Hutchison, \& Farris II, 2019), it is explained that management must be able to develop strategies in order to stabilize liquidity by paying attention to the profit to be achieved. When the company is concerned with high liquidity, following the risk and return trade-off, the profit generated will be low because it has low investment risk. It is supported by research (Eljelly, 2013), which states that liquidity and profitability are two important variables for the company because they have contradictory relationships, so they become important points for managers to make strategies to achieve company goals.

This research was conducted on companies that are members of LQ45 and listed on the Indonesian stock exchange in 2007-2019. LQ45 is a calculation of 45 stocks selected through several criteria. One of the main criteria is a high level of liquidity. These shares are selected every six months so that the membership of these shares will always change (Saragih, 2020). The LQ45 Index shows a high level of liquidity. It certainly affects the level of the company's ability to pay the long-term debt, or called leverage, which is the moderating variable in this study. Leverage is "a balance between the use of own capital and the use of debt, which means how much own capital and how much debt will be used, so that it can be taken into consideration in taking debt policies" (Kadim \& Sunardi, 2019).

Based on the phenomenon of fluctuations in the PBV ratio in LQ45 stocks, inconsistent results of previous studies, and there is a theoretical gap, the authors are interested in researching with the title "The Effect of Profitability on Firm Value with Leverage as a Moderating Variable in Companies Joined in LQ45 and Listed on the IDX in 2007 -2019”.

\section{Framework}

Following the description of the background of the problem, literature review, and previous research, a conceptual research framework is prepared as follows: 
Regina Clara Febrinta Br Bukit et.al. The effect of profitability and liquidity on firm value with leverage as moderating variable in companies that are joined in LQ45 and listed on the Indonesia stock exchange for the period 2007-2019.

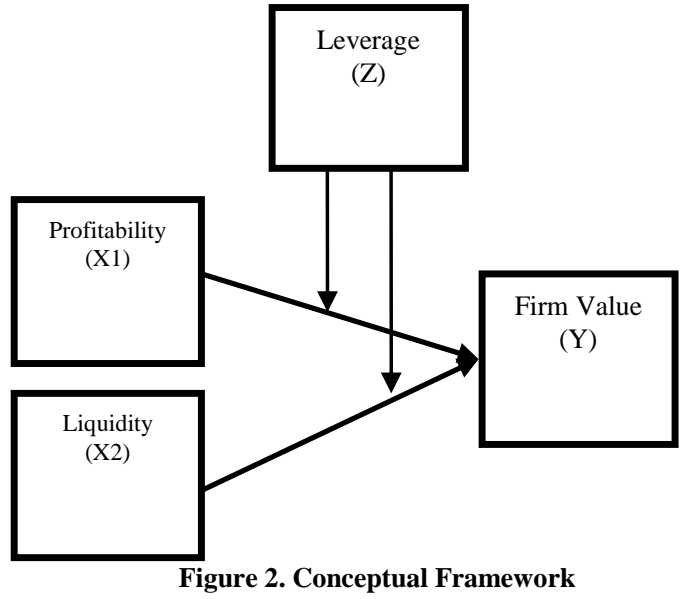

H1: Profitability has a positive effect on firm value.

$\mathrm{H} 2$ : Liquidity has a positive effect on firm value.

H3: Profitability and Liquidity simultaneously affect the Firm Value.

H4: Profitability has an effect on Firm Value with Leverage as a moderating variable.

H5: Liquidity has an effect on Firm Value with Leverage as a moderating variable.

H6: Profitability and liquidity simultaneously affect firm value with leverage as a moderating variable.

\section{RESEARCH METHODS}

This type of research is causal associative research to determine Profitability and Liquidity as an independent variable on Firm Value as the dependent variable with Leverage as the moderating variable. The causal associative study analyzes the relationship between one variable and another to know how one variable affects other variables (Erlina, 2011). The data analysis method used in this study is a statistical analysis method using the R-Statistics Application. Data analysis performs by testing standard assumptions and testing hypotheses.

The method of determining the sample uses purposive sampling so that a sample of 10 companies is multiplied by 13 years of research so that 130 observations are obtained.

\section{RESULT AND DISCUSSION Normality Test}

$>$ ks.test(models̄residuals, écdf(modè1Sresiduals))

one-sample kolmogorov-Smirnov test

data: mode1Sresiduals

$D=0.0076923, p$-value $=1$

alternative hypothesis: two-sided

Source: $R$ Studio data processing results

Figure 3: Normality Test with One Sample Kolmogorov Smirnov

From the results of the $\mathrm{R}$ Studio data processing, it is known that the normality test with the One-Sample Kolmogorov Smirnov Test in this study has a value of D $=0.0076923, \mathrm{p}$-value $1(0.05)$. So it can be concluded that the data in this study were normally distributed and met the assumption of normality.

\section{Hypothesis test}

\section{Multiple Linear Regression Analysis}

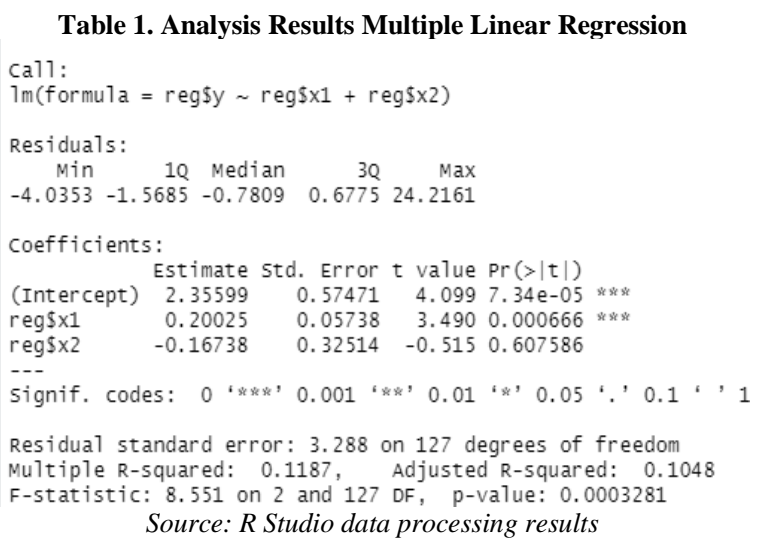

Based on Table 1, profitability has a positive effect on firm value, while liquidity has a negative effect on firm value.

\section{Coefficient of Determination Test}

Based on Table 1. above, the value of $\mathrm{R}$ square (is 0.1187 or $11.87 \%$ of the independent variables, namely profitability and liquidity, can explain the firm value. In contrast, the remaining $88.13 \%$ is explained or influenced by other variables not included in the research model. 
Regina Clara Febrinta Br Bukit et.al. The effect of profitability and liquidity on firm value with leverage as moderating variable in companies that are joined in LQ45 and listed on the Indonesia stock exchange for the period 2007-2019.

\section{T-Test (t-test)}

Based on Table 1. above, it can be concluded that:

1. The significance value of profitability (X1) has an effect on firm value (Y) of 0.20025 with a significance of 0.000666 $<=0.05$, then profitability $(\mathrm{X} 1)$ has a positive and significant effect on firm value (Y). Score $t_{\text {count }}=3,490>$ $t_{\text {tabel }}=1,657$. So profitability (X1) has a significant effect on firm value (Y). $\mathrm{H1}$ is accepted.

2. The significance value of liquidity (X1) has an effect on firm value (Y) of 0.16738 with a significance of 0.607586 $>=0.05$. It means that liquidity $(\mathrm{X} 2)$ has a negative and insignificant effect on firm value (Y). $t_{\text {count }}=-0.515<$ $t_{\text {tabel }}=1,657$. So liquidity (X2) does not affect firm value (Y). $\mathrm{H2}$ is rejected.

\section{F-Test (F-Test)}

Based on Table 1. Above the results of the R Studio Simultaneous Test (F) data processing, it is known that the p-value is 0.0003281 , and the calculated $\mathrm{f}$ value is 8.551. So it can be concluded that jointly profitability and liquidity affect firm value. $\mathrm{H3}$ is accepted.

\section{Moderated Regression Analysis (MRA)}

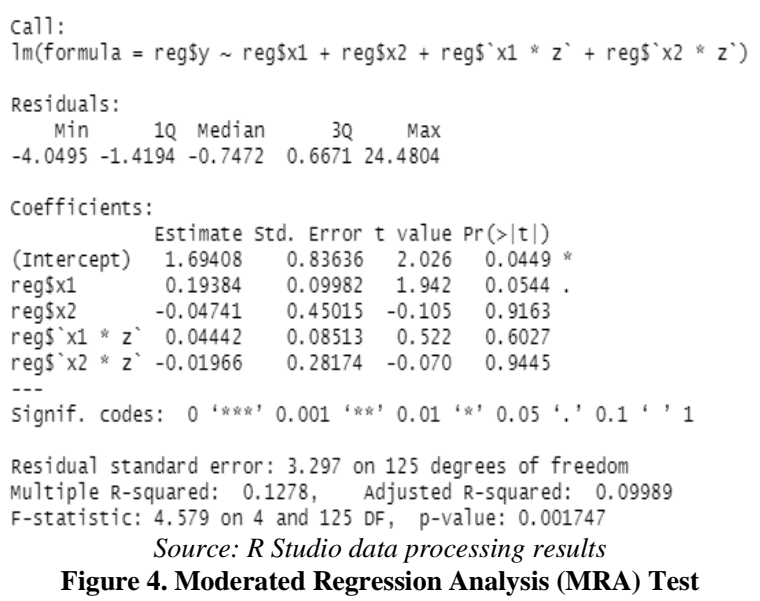

Figure 4. Moderated Regression Analysis (MRA) Test

\section{Coefficient of Determination Analysis Moderating Test}

Based on Figure 4. above, the value $=0.1278$ is greater than the previous value, namely 0.1187 , which shows that leverage can moderate the relationship between profitability and liquidity to firm value by $12.78 \%$.

\section{T-Test (t-test)}

Based on Figure 4. it can be concluded that:

1. The regression coefficient value of the interaction of profitability with leverage is 0.04442 with a significance level of $0.6027>$ taraf level $=0.05$, while the $\mathrm{t}$ value $=0.522<\mathrm{t}$ table value $=1.657$. These results indicate that leverage is not able to moderate the relationship between profitability and firm value. H4 is rejected.

2. The regression coefficient value of liquidity interaction with leverage is 0.01966 with a significance level of $0.9445>$ level $=0.05$, while the $t$ value $=-0.070>\mathrm{t}$ table value $=1.657$. These results indicate that leverage is not able to moderate the relationship between liquidity and firm value. $\mathbf{H 5}$ is rejected.

\section{F-Test (F-Test)}

Based on Figure 4. it is known that the calculated $F$ value $=4.579$ and the $p$ value $=0.09989$. So it can be concluded that leverage can moderate profitability and liquidity on firm value simultaneously (simultaneously). H6 is accepted.

\section{CONCLUSION}

Based on the results of data analysis and research discussion, the following conclusions can be drawn:

1. Profitability partially has a positive and significant effect on company value in companies that are members of LQ 45 and listed on the Indonesia Stock Exchange for the period 2007-2019.

2. Liquidity partially has a negative and insignificant effect on company value in companies that are members of LQ 45 and listed on the Indonesia Stock Exchange for the period 2007-2019.

3. Profitability and liquidity simultaneously have a positive and 
Regina Clara Febrinta Br Bukit et.al. The effect of profitability and liquidity on firm value with leverage as moderating variable in companies that are joined in LQ45 and listed on the Indonesia stock exchange for the period 2007-2019.

significant effect on firm value in companies that are members of LQ 45 and listed on the Indonesia Stock Exchange for the period 2007-2019.

4. Leverage weakens the influence of profitability on company value in companies that are members of LQ 45 and listed on the Indonesia Stock Exchange for the period 2007-2019.

5. Leverage weakens the influence of liquidity on company value in companies that are members of LQ 45 and listed on the Indonesia Stock Exchange for the period 2007-2019.

6. Leverage strengthens the influence of Profitability and Liquidity on company value simultaneously in companies that are members of LQ 45 and listed on the Indonesia Stock Exchange for the period 2007-2019.

\section{RESEARCH LIMITATIONS}

The results of this study have limitations where the contribution of the dependent variable in this study is very small, affecting the firm value of $11.87 \%$, other variables outside this study influences the remaining $88.13 \%$.

\section{SUGGESTION}

Based on the conclusions and limitations that have been found, the researcher provides several suggestions, including:

1. For further researchers, other indicators can be used to measure company value other than this research variable to be used as comparison materials regarding the consistency of using proxies. Moreover, further researchers are also expected to add other factors.

2. For companies, as a material consideration in the use of debt in carrying out company operations.

3. For investors, it is hoped that the results of this study can be used as a reference in considering making decisions to invest in companies listed in LQ 45 listed on the Indonesian Stock Exchange.
Acknowledgement: None

Conflict of Interest: None

Source of Funding: None

\section{REFERENCES}

1. Astriani, E. F. (2014). Pengaruh Kepemilikan Manajerial,Leverage, Profitabilitas,Ukuran Perusahaan dan Investment Opportunity Set terhadap Nilai Perusahaan studi Pada Perusahaan Manufaktur yang Terdaftar di Bursa Efek indonesiatahun 2009-2011. Skripsi. http://ejournal.unp.ac.id/students/index.php/ akt/article/view/904/654

2. Baz, J., Sapra, S., Stracke, C., \& Zhao, W. (2021). Valuing a Lost Opportunity: An Alternative Perspective on the Illiquidity Discount. The Journal of Portfolio Management, 47(3), 112-121. https://doi.org/10.3905/jpm.2020.1.197

3. Chen, Y., Sensini, L., \& Vazquez, M. (2021). Determinants of Leverage in Emerging Markets: Empirical Evidence. International Journal of Economics and Financial, 11(2), 40-46. https://doi.org/10.32479/ijefi.10997

4. Chumaidah, \& Priyadi, M. P. (2018). Pengaruh Profitabilitas dan Size Terhadap Nilai Perusahaan Dengan CSR Sebagai Variabel Pemoderasi. Jurnal Ilmu dan Riset Akuntansi, 7 no 3 , 120.https://www.bing.com/search?Q=pengar $\mathrm{uh}+$ profitabilitas+dan+size+terhadap+nilai+ perusahaan+dengan $+\mathrm{csr}++$ sebagai+variabel +pemoderasi $\& \mathrm{qs}=\mathrm{n} \&$ form $=\mathrm{qbre} \& \mathrm{sp}=1 \& \mathrm{pq}$ =pengaruh+profitabilitas+dan+size+terhada p+nilai+perusahaan+den

gan+csr+sebagai+variabel+pemoderasi\&s

5. Czerwonka, L., \& Jaworski, J. (2021). Meta-Study On The Relationship Between Profitability and Liquidity of Enterprises in Macroeconomic and Institutional Environment.

https://doi.org/10.1007/s40622-021-00280-y

6. Dessyana. (2016). Faktor-Faktor Yang Mempengaruhi Nilai Perusahaan Pada Perusahaan Manuaktur Yang Terdatar di Bursa Efek Indonesia dengan Profitabilitas Sebagai Variabel Intervening. Tesis, Universitas Sumatera Utara.

7. Du, Jinmin, Fei, W., \& Xing Yun Liang. (2016). Corporate Liquidity and Firm Value: Evidence From Cina's Listed From Firms. EDP Sciences, 1-4. 
Regina Clara Febrinta Br Bukit et.al. The effect of profitability and liquidity on firm value with leverage as moderating variable in companies that are joined in LQ45 and listed on the Indonesia stock exchange for the period 2007-2019.

http://dx.doi.org/10.1051/shsconf/20162401 013.

8. Erlina. 2011. Metodologi Penelitian. Medan: USU Press.

9. Ganiyu, O., Ebenezer, M., Adewale , L., \& Isiaq, K. (2021). Operating Leverage And Firm Value of Manufacturing Firms in Nigeria. International Journal of Commerce and Finance, 77-91. http://ijcf.ticaret.edu.tr/index.php/ijcf/article /view/247/pdf_148

10. Hertina, D., Hidayat, M. H., \& Mustika, D. (2019, April). Ukuran Perusahaan, Kebijakan Hutang Dan Profitabilitas Pengaruhnya Terhadap Nilai Perusahaan. Jurnal Ecodemica, 3 no.1. https://doi.org/10.31294/jeco.v3i1.5456

11. Husain, T., Sarwani, Sunardi, N., \& Lisdawati. (2020). Firm's Value Prediction Based on Profitability Ratio and Dividend Policy. Finance \& Economics Review, 2(2), 13-26. http://dx.doi.org/10.38157/financeeconomics- review.v2i2.102

12. Ibrahim, U., \& Isiaka, A. (2021). Dynamic modeling of the relationship between financial leverage and firm value of selected firms quoted on the Nigerian Stock Exchange. Research in Business \& Social Science, 10(3), 259-275. https://doi.org/10.20525/ijrbs.v10i3.1024

13. Janabi, M. (2021). The Importance of Measuring Liquidity Risk with Smart Financial Applications. Economic Research Forum (ERF), 1-5. https://dx.doi.org/10.2139/ssrn.3841253

14. Kadim, \& Sunardi. (2019). , Vol.3, No.1, September201922Pengaruh Profitabilitas ,Ukuran Perusahaan Terhadap Leverage Implikasi Terhadap Nilai Perusahaan Cosmetics and Householdyang terdaftar di Bursa Efek Indonesia. Jurnal Sekuritas, 2581-1696.

15. Kalbuana, N., Lamtiar, S., \& dkk. (2021). Liquidity Effect, Profitability Leverage to Company Value: A Case Study Indonesia. European Journal of Molecular \& Clinical Medicine, $\quad 7(11), \quad$ 2800-2822. https://www.ejmcm.com/pdf_6290_46a61f7 40ecf59c94fb64f1139f6891f.html

16. Kodongo, Mokoaleli-Mokoteli, O., Maina, T., \& Leonard. (2021). Capital structure, profitability, and firm value: Panel Evidence of listed firms in Kenya. Federal Reserve Bank of St Louis. https://www.researchgate.net/publication/26
3655553_Capital_structure_pr ofitability_and_firm_value_Panel_evidence _of_listed_firms_in_Kenya

17. Lalithchandra, B., \& Rajendhiran, D. (2021). Liquidity Ratio: An Important Financial Metrics. Turkish Journal of Computer and Mathematics Education, 12(2), $1113 \quad-1114$. http://dx.doi.org/10.17762/turcomat.v12i2.1 129

18. Le, H., \& Gregoriou, A. (2021). Liquidity and asset pricing: evidence from a new freefloat-adjusted price impact ratio. Journal of Economic Studies. https://doi.org/10.1108/JES-04-2021-0182

19. Maani, A., Alawad, A., \& Karaki, B. (2021). Impact of Liquidity and Profitability Ratios on The Stock Market Value of Jordan Insurance Companies. Academy Of Accounting and Financial Studies Journal, 2(1). Retrieved from https://www.abacademies.org/articles/Impac t-of-liquidity-and- profitability-ratios-onthe-stock-market-value-of-jordan-insurancecompanies-1528-2635-25-2-698.pdf

20. Machmuddah, Z., Sari, D., \& Utomo, S. (2020). Corporate Social Responsibility, Profitability and Firm Value: Evidence from Indonesia. Journal of Asian Finance, Economics, and Business, 17(9), 631-638. http://dx.doi.org/10.13106/jafeb.2020.vol7.n 09.631

21. Mariana, Abdullah, S., \& Mahmud, M. (2020). Corporate Governance Perception Index, Profitability and Firm Value in Indonesia. Technology and Investment, 11, 13-21. http://dx.doi.org/10.4236/ti.2020.112002

22. Osazuwa, N., \& Ahmad, A. (2016). The moderating effect of profitability and leverage on the relationship between efficiency and firm value in publicly traded Malaysian firms. Social Responsibility Journal, 12(2), 295-306. https://doi.org/10.1108/SRJ-03-2015-0034

23. Othman, H. A., \& Haron, R. (2021). Hedging, managerial ownership, and firm value. Journal of Asian Business and Economic Studies, 2515.

24. Pazos, D., Lopez, S., \& Arez, L. (2021). Impact of Working Capital Management on Profitability for Spanish fish canning companies. Marine Policy, 1-10. https://doi.org/10.1016/j.marpol.2021.10458 3 
Regina Clara Febrinta Br Bukit et.al. The effect of profitability and liquidity on firm value with leverage as moderating variable in companies that are joined in LQ45 and listed on the Indonesia stock exchange for the period 2007-2019.

25. Pratiwi, H., Wijaya, R., Sari, D. P., \& Yengsih, R. M. (2020). The Effect of Liquidity and Working Capital on Corporate Values With Profitability as Moderating Variables in Manufacturing Companies Listed on IDX. Dinasti International Journal Of Economics, Finance, Accounting, 1, 1-7. https://doi.org/10.38035/dijefa.v1i1.199

26. Puspitasari, E., Sudiyatno, B., \& Hartoto, W. (2021, Januari). Net Interest Margin and Return on Assets: A Case Study in Indonesia. Journal of Asian Finance, Economics, and Business, 8(4), 727-734. https://doi.org/10.13106/jafeb.2021.vol8.no 4.0727

27. Putra, A., \& Lestari, V. (2016). Pengaruh Kebijakan Dividen, Likuiditas, Profitabilitas dan Ukuran Perusahaan Terhadap Nilai Perusahaan. E-Journal Manajemen UNUD, 5(7), 4044-4070. https://media.neliti.com/media/publications/ 253133-pengaruh-kebijakan- dividenlikuiditas-pr-3fa88dfa.pdf

28. Rahayu, M., \& Sari, B. (2018). FaktorFaktor Yang Mempengaruhi Nilai Perusahaan. Ikraith Humaniora, 2(2). https://media.neliti.com/media/publications/ 226369-faktor-faktor-yang- mempengaruhinilai-pe-59d2eeff.pdf

29. Saragih, H. P. (2020, April 7). Fantastis! 5 Saham LQ45 Melesat 30\% Lebih dalam Sepekan. cnbcindonesia.com: https://www.cnbcindonesia.com/market/202 00407085846-17-150195/fantastis-5-sahamlq45-melesat-30-lebih-dalam-sepekan

30. Sari, N. S., \& Suryantini, N. S. (2019). Pengaruh Profitabilitas, Likuiditas, dan Tingkat Pertumbuhan Terhadap Kebijakan Dividen pada Perusahaan Manufaktur. EJurnal Manajemen, 8(7), 4559-4588. https://doi.org/10.21744/irjmis.v7n1.828

31. Setyawan, J., Siregar, R., Sherly, \& Butarbutar, N. (2019). Pengaruh Likuiditas Terhadap Nilai Perusahaan dengan Leverage sebagai Variabel Intervening Pada PT Unilever Tbk Yang Terdaftar Di Bursa
Efek Indonesia. Jurnal Manajemen Dan Keuangan, $\quad 7(2), \quad 32-42$. https://doi.org/10.37403/sultanist.v7i2.150

32. Sriwahyuni, U., \& Wihandaru. (2016). Pengaruh Profitabilitas, Leverage, Kepemilikan Institusional, dan Investment Opportunity Setterhadap Nilai Perusahaan Dengan Kebijakan Dividen Sebagai Variabel Intervening pada Perusahaan Manufaktur Yang Terdaftar Di Bei Periode 2010-2014. Program Studi manajemenfakultas Ekonomi Universitas Muhammadiyah Yogyakarta, 7 no.1. https://journal.umy.ac.id/index.php/mb/artic le/view/3904/3374

33. Sukarya, I. P., \& Baskara, I. K. (2019). Pengaruh Profitabilitas, Leverage dan Likuiditas Terhadap Nilai Perusahaan Sub sektor Food and Beverages. E-Journal Management, 8(1), 2302-8912. https://doi.org/10.24843/EJMUNUD.2019.v 08.i01.p16

34. Wabwile, E., Chitiavi, M., Alala, D., \& Douglas, d. (2014). Financial Leverage and Performance Variance a Mong Banks. Evidence of Tier 1 Commercial Banks Listed on Nairobi Security Exchange Kenya. International Journal of Business and Management Invention, 3(4), 1-13. http://ijbmi.org/papers/Vol(3)4/Version2/A034201013.pdf

35. Yang, J., \& Suh, H. (2021). Heterogeneous Effects of Macroprudential Policies on Firm Leverage and Value. South Korea: https://dx.doi.org/10.2139/ssrn.3837044

How to cite this article: Regina Clara Febrinta Br Bukit, Muda I, Abubakar E. The effect of profitability and liquidity on firm value with leverage as moderating variable in companies that are joined in LQ45 and listed on the Indonesia stock exchange for the period 20072019. International Journal of Research and Review. 2021; 8(7): 344-352. DOI: https://doi. org/10.52403/ijrr.20210748 